International Journal of Forensic Science \& Pathology (IJFP)

ISSN 2332-287X

\title{
An Autopsy Evaluation of Complete Decapitation Injuries
}

Dinesh Rao

Ex Director and Chief Forensic Pathologist, Kingston, Department of Forensic Medicine, SIMS, Bangalore, India.

\begin{abstract}
Complete Decapitations are not uncommon in routine Forensic Autopsies. In this study Complete Decapitations were found in $0.67 \%$ of Autopsies of which $96.15 \%$ [n-25] were Homicidal and 3.85\% [n-1] due to Suicide. Only in 26.92\% [n-07] of cases Decapitations were done during the process of death and in $73.08 \%$ [n-19] of Decapitations were done Postmortem. The Majority of the Victims belonged to $3^{\text {rd }}[\mathrm{n}-11]$ and the $4^{\text {th }}[\mathrm{n}-10]$ Decade. The Male to Female Ratio was $2: 1$. In $21[84 \%]$ cases the Head was recovered from the River/riverside Bush, away from the place of residence and in 04 [16\%] cases the Head was recovered along with the Torso around the Place of Residence. Major number of cases [n-24] were due to Gang related violence and in 2 cases Love and Sex dominated the incident. In $92.31 \%$ [n-24] of cases the C2-3 was involved and in two cases other cervical vertebra were involved. The Thyroid was least affected [n-5] and major number of Decapitations [n-15] were carried out above the Thyroid cartilage and in 6 cases below the thyroid Cartilage. A decapitation was the Proximate Cause of Death in 07 cases, though associated with other nonfatal or near fatal injuries. Decapitations demonstrated extreme degree of violence and Mutilation. It is also a result of high degree of Offensive, Defensive and aggression. Public Display of Head in Complete Decapitation is a method to impose a sense of Fear, it is a mean to Propaganda and Intimidation.
\end{abstract}

Keywords: Complete Decapitations; Homicide; Exsanguinations; Conceal; Postmortem.

\section{*Corresponding Author:}

Dr. Dinesh Rao,

Ex Director and Chief Forensic Pathologist, Kingston, Department of Forensic Medicine, SIMS, Bangalore-90, India.

E-mail: dineshrao22@yahoo.com

Recieved: March 13, 2015

Accepted: March 27, 2015

Published: April 01, 2015

Citation: Dinesh Rao (2015) An Autopsy Evaluation of Complete Decapitation Injuries, Int J Forensic Sci Pathol. 3(4), 99-104. doi: http:// dx.doi.org/10.19070/2332-287X-1500024

Copyright: Dinesh $\mathbf{R a o}^{\circ}$ 2015. This is an open-access article distributed under the terms of the Creative Commons Attribution License, which permits unrestricted use, distribution and reproduction in any medium, provided the original author and source are credited.

\section{Introduction}

Complete Decapitation is the separation of the head from the body. Internal Decapitation is atlanto-occipital dislocation, or orthopedic decapitation describes the rare medical condition in which the skull separates from the spinal column during severe head injury. Beheading typically refers to the act of intentional decapitation, either as a means of murder or execution; Accidental decapitation can be the result of an explosion [1], Road Accident or industrial accident, improperly administered execution by hanging or other violent injury. Suicide by decapitation is rare, but not unknown [2]. The national laws of Saudi Arabia, Yemen, Iran, and Qatar permit beheading, but Saudi Arabia is the only country that continues to behead its offenders [3]. IN SA According to Amnesty International, at least 79 people were executed in the kingdom in 2013 [4]. Foreigners are not exempt, accounting for "almost half" of executions in 2013 [4]. In majority of the Homicidal Decapitations it is done to take the head as a trophy, for public display, to make the deceased more difficult to identify, for cryonics, or for other reasons [5, 6] Public display of the heads of executed persons, and of decapitated bodies, has served as a form of political propaganda or intimidation both in historical and in modern times. Islamic Rebel forces have regularly carried out beheadings of people. Historically, decapitation had been the most common method of execution in Korea, until it was replaced by hanging in 1896. Recently during the Mexican Drug War some Mexican drug cartels have turned to decapitation and beheading of rival cartel members as a method of intimidation [7]. Hence Beheadings are not uncommon and careful Examination is necessary to understand the Motive behind the act, it is also important to differentiate the Homicidal, suicidal and Accidental nature of the act because postmortem Decapitations are common. Hence the present study makes an attempt to study the Complete Decapitations in Autopsy.

\section{Materials and Methods}

All the Forensic Autopsy under Coroner's Inquest referred to the Legal Medicine Unit was the Material for the Study. The prospective Study was conducted between the periods 2009 to 2012. Each cases was analyzed based on its Age Sex, Place recovered [both Torso and Head], Circumstances under which Beheadings were done. The investigative details pertaining to the Perpetrators were 
made available from the Investigating Officer and The Crime $\mathrm{Bu}$ reau to analyze the motive behind the Crime and Circumstances. The Autopsy examination to know the Cause of death, Ante mortem and Postmortem Nature of Decapitations, The level of the Neck involved Other Associated Fatal and Non Fatal injuries over the Body. Crime scene examination done in all the cases to understand the Circumstances behind the Beheadings. The contribution of each injury over the body to the Cause of death was analyzed in all the cases to understand the Cause of Death and the Ante and Postmortem nature of Beheadings.

\section{Results}

1. A total of 3907 Autopsies were conducted during this period of Study. Only in 26 cases Beheadings were reported contributing to $0.67 \%$ [n-26] of the total Autopsies.

2. The Male to Female Ratios was 2:1.

3. Majority of the Victims belonged to the age group $3^{\text {rd }}$ [n-11] to $4^{\text {th }}$ Decade $[\mathrm{n}-10]$. Individual below the age 10 and above 40 were unaffected. Only 5 cases were reported in the $2^{\text {nd }}$ Decade.

4. Majority of the Decapitations were reported in Homicidal Cases contributing to $96.15 \%$ [n-25] of cases and only $3.85 \%$ [n-1] cases were due to Suicide, No Accidental Decapitation were reported. The cause of Suicide was Railway Accident

5. Of the Total number of Decapitations $73.08 \%$ [n-19] of the Decapitations were Postmortem in Nature and in 26.92\% [n7] of Cases Decapitations were done either before Death or during the process of Death.

6. Majority of the Decapitated Heads [n-21] in Homicides, were recovered away [1-2kms range] from the scene of crime, either in the River or River side bushes. In Five cases the same was recovered in the vicinity [1-10mts] of which one [suicidal [Railway injury] was recovered at the Crime Scene.

7. Gang related Violence were the Major factors associated with Decapitations in 24 cases. In Two cases Sex or Love related factors contributed to Decapitations.

8. In $92.31 \%$ [n-24] of cases the C2-3 were involved and in two cases other cervical vertebra were involved. The Thyroid Cartilage was least affected, it was involved in only 05 cases and major number of Decapitations [n-15] were carried out above the Thyroid cartilage followed by the level below the thyroid Cartilage in 06 Cases. Moderately heavy Sharp Cutting Edged Weapons like Machete was used.

9. Decapitations was the Proximate Cause of Death in 07 cases, wherein the Decapitations were carried out before Death or at the time of Death. In 19 cases the Decapitations were carried out after the Death of the Individual. In both categories there were various Fatal and Near Fatal injuries were present of which the Gunshot wound contributed to $53.84 \%$ [n-14] of the cases followed by Chop wounds in 26.92\% [n-07] of cases, Stab wounds in $15.38 \%$ [n-04] of cases. Blunt injuries present in 01 cases of Suicidal Railway Accident.

\section{Discussion}

Complete Decapitations in Homicides are associated with fatal or near fatal [mutilations] injuries [8]. Accidental Decapitations and Suicidal Decapitations [9] are reported, Postmortem Dismemberment of bodies are not uncommon following Homicide [10].

In the present Autopsy study of Complete Decapitations a total of 26 cases were reported of the 3907 autopsies contributing to $0.67 \%$ of the Autopsies in a Four year period, this observations are contrary to those made be similar study conducted by Bahadur Kumral et al [2012] wherein only 19 cases [0.05\%] were reported out of 36270 Autopsies.

In a study conducted by Tsokos et al [12] only 10 cases reported of the total 7681 Autopsies. Hence the influence of regional issues, socioeconomic factors plays an important role. However it is obvious that Decapitations contribute to only a small percentage of the total Autopsies. In the present study the age group of the Victims were between 20-40 years and Male to Female ratio was 2:1, an observation varying with those of Bahadur Kumral et al who viewed that the victims belonged to the age group 18-71 and the Male to Female Ratio 1:4. This variation are possible due to different regions of study and majority of his victims were due to Accident and Homicides, unlike the present study wherein Majority of the Complete Decapitations were Homicides in $96.15 \%$ [n-25] of cases and only one case Suicidal Decapitations was reported [3.85\%]. The individuals less than 10 years and more than 40 years were unaffected because of the possibility that they were either not entertained or accepted in that period of Life. The other reason may be because young Adults are easily attracted and trapped in Gangs in the guise of factions, fast money, Cars, drugs as compared to very young and late Adulthood individuals. A Majority of Decapitations were Postmortem contributing to $73.08 \%$ [n-19] of cases and in only $26.92 \%$ [n-7] of cases the Victims were decapitated before or during the process of death. In all this cases the process of exsanguinations, subendocardial haemorrhages, Respiratory system findings due to aspiration of Blood and the presence of vital reactions were considered to confirm the Ante mortem Nature of Decapitations apart from Fat embolism findings $[13,14]$. The subendocardial hemorrhages developed as a result of Shock developing due to Hypovolumia seen in the Cases of this nature. The validity of Vital signs should be carefully accounted as its well noted that Vital signs are present in decapitations done in a short time after the death $[15,16]$. Hence careful examination of the Injuries present on the body and there Potential to cause fatality need to be analyzed. Two of the cases in the present study, the Head was recovered few weeks after the incident. In these cases the DNA evidence [17] was used to match with the torso apart from other identification parameters like color, sex, age factors.

The most important observations made in the present study was the recovery of the Decapitated Head [Table 4], in majority of the cases of Homicidal Decapitations the Head was recovered 1-2 $\mathrm{kms}$ away from the Actual scene of offence [torso] in 21 cases and in only 4 cases the Head was recovered in its vicinity [2-10 mts]. The head was recovered close to the torso in one case of Suicide due to train related fatality. In the present study the motive behind Decapitations were Gang related Violence in 24 cases and in one case it was Sex related, The Case of Suicide was the result of Relations ship Crisis. The Victims of Gang related violence were mainly due to fallout from the Gang, betrayal, suspected police informer, witness, cross over to other gang and non compliance of Gang orders. In Cases of Homicidal Decapitations involving Mutilations and Postmortem Dismemberment the motive behind abandoning the Head away from the Scene of Offence was mainly to conceal the Identity of the Victim. Secondly to spread the word of Terror or Fear among the community by this act of Complete Decapitation] as a punishment for interfering in the Perpetrators activities. Thirdly it indicates the necromaniac muti- 
Table 1. Indicating the Total number of Autopsies and Decapitations.

\begin{tabular}{|c|c|c|}
\hline HOMICIDES & TOTAL NO & PERCENTAGE \\
\hline TOTAL AUTOPSY & 3907 & $100 \%$ \\
\hline DECAPITATION INJURIES & 26 & $0.67 \%$ \\
\hline
\end{tabular}

Table 2. Indicating the Age and Sex distribution of cases.

\begin{tabular}{|c|c|c|c|c|c|}
\hline AGE & $0-10$ & $20-$ Nov & $21-30$ & $31-40$ & $41-50$ \\
\hline MALES & 00 & 03 & 09 & 06 & 00 \\
\hline FEMALES & 00 & 02 & 02 & 02 & 00 \\
\hline TOTAL & 00 & $05[19.23 \%]$ & $11[42.31 \%]$ & $08[30.77 \%]$ & 00 \\
\hline
\end{tabular}

Table 3. Indicating the Type of Decapitation and Nature of Decapitations.

\begin{tabular}{|c|c|c|c|}
\hline Type & No & Antemortem[26.92\%] & Postmortem[73.08\%] \\
\hline Homicidal & $25[96.15 \%]$ & 06 & 19 \\
\hline Accidental & 00 & 00 & 00 \\
\hline Suicidal & $01[3.85 \%]$ & 01 & 00 \\
\hline Total & 26 & 07 & 19 \\
\hline
\end{tabular}

Table 4a. Indicating the Place or Recovery of Decapitated Head.

\begin{tabular}{|c|c|c|}
\hline Place of Recovery & Total & Percentage \\
\hline At the Scene & 01 & $3.85 \%$ \\
\hline In the vicinity[few meters] & 04 & $15.38 \%$ \\
\hline Away from Crime scene[>1 kms] & 21 & $80.77 \%$ \\
\hline
\end{tabular}

Table 4b. Indicating the Motive in Homicidal Decapitations.

\begin{tabular}{l|l|l|l|} 
MOTIVE & GANG RELATED 24 & SEX/LOVE RELATED-02 & TERRORISM-00 \\
\hline
\end{tabular}

Table 5. Indicating the Morphology of the Decapitated Wound.

\begin{tabular}{|c|c|c|c|}
\hline SL No & MORPHOLOGY PATTERN & TOTAL & PERCENTAGE \\
\hline 01 & MARGINS & CLEAN CUT & $100 \%$ \\
& & REGULAR WITH CONTUSION OF THE MARGINS. & $3.85 \%$ \\
& & PALE MARGINS . & $73.08 \%$ \\
\hline 02 & NO OF SKIN CUTS & MIN-3,MAXIMUM-08 & -- \\
\hline 06 & THYROID CARTILAGE & ABOVE THE THYROID CARTILAGE-15 & $57.69 \%$ \\
& & ACROSS THE THYROID CARTILAGE-05 & $19.23 \%$ \\
& & BELOW-06 & $23.07 \%$ \\
\hline 07 & CERVICAL VERTEBRA & C2-3VERTABRA-24 & {$[92.31 \%]$} \\
& & C1-2 VERTEBRA-01 & {$[3.85 \%]$} \\
& & C3-4VERTABRA-01[3.85\%] & {$[3.85 \%]$} \\
\hline
\end{tabular}

Table 6. Indicating the Type of Injuries present on the Bodies.

\begin{tabular}{|c|c|c|c|}
\hline SL No & TYPE OF INJURY & TOTAL NO & PERCENTAGE \\
\hline 1 & GUNSHOT WOUND & 14 & $53.84 \%$ \\
\hline 2 & CHOP WOUND & 07 & $26.92 \%$ \\
\hline 3 & STAB WOUNDS & 04 & $15.38 \%$ \\
\hline 4 & RAILWAY ACCIDENT & 01 & $03.84 \%$ \\
\hline
\end{tabular}


Figure 1. Decapitated Head Recovered Four Days later from River with Chop Wound.

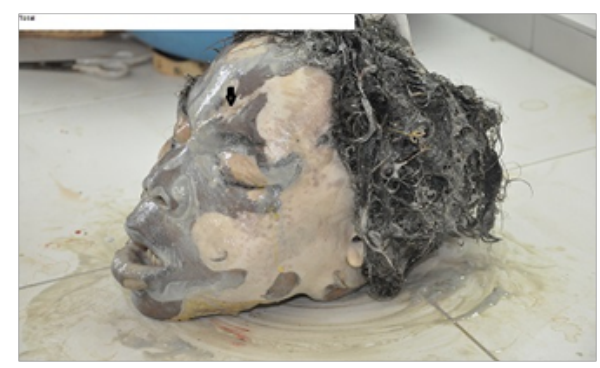

Figure 2. The Torso with Multiple Tissue Tags belongs to Head in Figure 1.

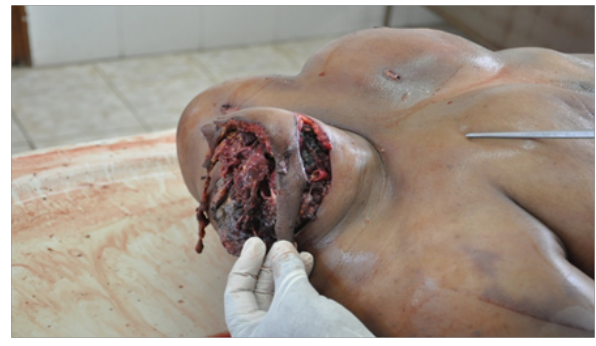

Figure 3. shows the Torso with Three Wedge shaped Tissue Tags in Complete Homicidal Decapitation.

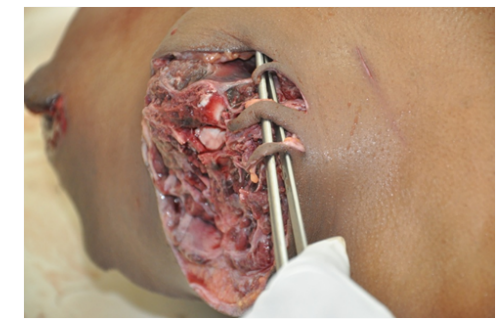

Figure 4. Homicidal Postmortem Decapitated Head.

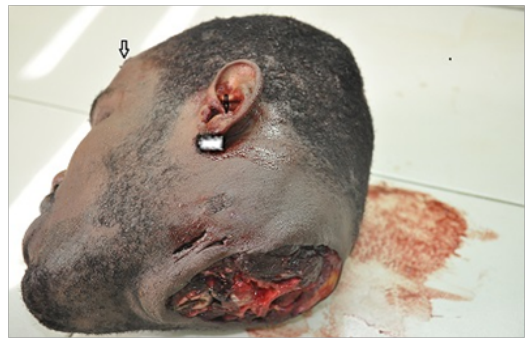

Figure 5. Torso with circular Tissue tag in Suicidal Decapitation due to Railway Injury.

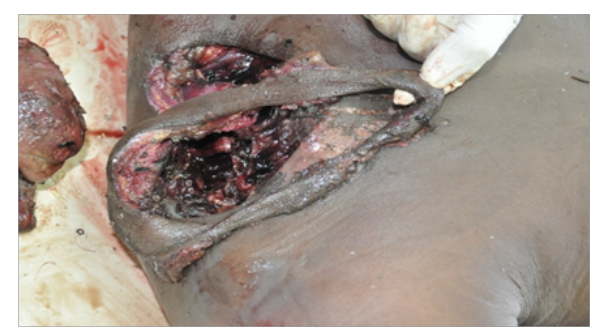

lation in an outrageous killing. Fourthly it always indicative of an Aggravated Attack on individual against disloyality, betrayel and so called backstabbers in a criminal organization. Fifthly it carries a signature of the [Group] Organization [18-20].

In the present study it was observed that Majority of the decapitations involved C2-3 Vertebra in 92.31\% [n-24] [Table 5] of cases and in only 2 cases it involved other vertebras, an observations varying from those made by Bahadur Kumaral et al [2012] [11], he observed that majority of his victims head were decapitated between C1-2 Vertebra. In the present study the level of Decapi- tation over the front of neck was studied though no comparison studies available elsewhere, the study indicated that The Thyroid Cartilage was least affected, it was involved in only 05 cases and major number of Decapitations [n-15] were carried out above the Thyroid cartilage followed by the level below the thyroid Cartilage in 06 Cases. Moderately heavy Sharp Cutting Edged Weapons like Machete was used. The margins of the wound indicated wedge shaped cuts; the number of wedge reflected the number of blow by the weapon. Hence the level of front of neck involvement is unpredictable given the outrageous and Necromaniac attitude of the perpetrator since there was no uniform pattern observed with 
Figure 6. Torso of victim in gunshot wound Death-Postmortem Decapitation.

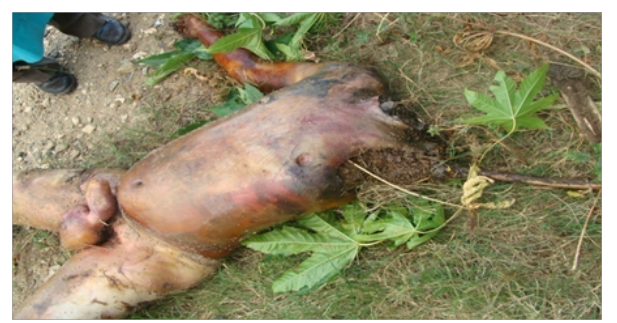

Figure 7. Showing Ante mortem Decapitation.

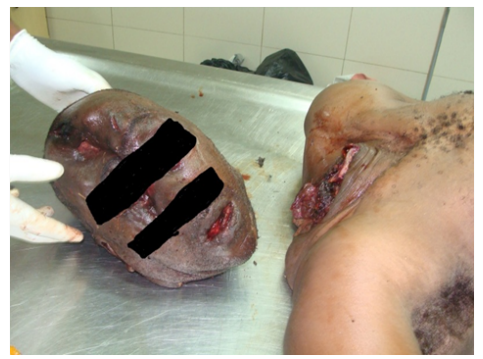

Figure 8. Decapitated Head recovered 10 days after the Crime.

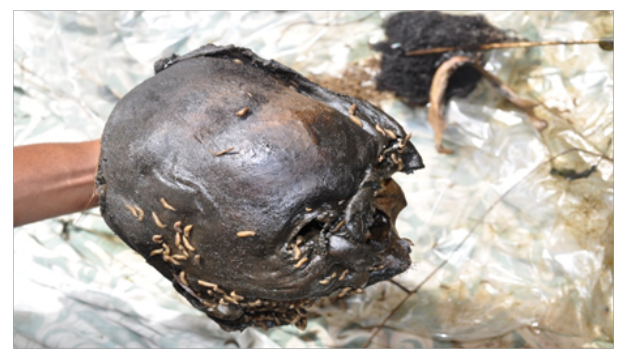

the different manner of Death. In the present study Postmortem Decapitations [Table 3] were reported in 19 cases of homicides, In 07 cases the Decapitations were carried out before or during the process of Death. Closer study of this cases indicated that the Gunshot wounds contributed to 53.84\% [n-14] [Table 6] of the Fatality followed by Chop wounds in $26.92 \%$ [n-07] of cases, Stab wounds in $15.38 \%$ [n-04] of cases. Blunt injuries present in 01 cases of Suicidal Railway Accident. This observations contrary to those made by Bahadur Kumaral et al [2012] [11] wherein he observed that majority of his Homicidal Victims bore Stab wounds and there were no Sex related Decapitations though one case was reported in the present study. The Regional, Socieconomic, Cultural and Political factors played a dominant role which need more Research involving multiple desclipnes. The present study involved Jamaica Nation wherein Drugs, Legal and Illegal Firearms and Machete are more common hence the Nature of injuries were different from those reported in Bahadur Kumaral et al [2012] region of Study. The Crime scene was processed in all the cases, the biological, material, weapon and trace evidences were retrieved to assist in identifying the number of Assailants, their affiliations and Identity. In all the victims the Toxicological study was done and none reported significant results, a finding contrary to those made by Bahadur Kumaral et al [2012] wherein he reported level of ethanol's from $120-375 \mathrm{mg} / 100 \mathrm{ml}$ blood. The reason being is majority of his victims involved road Traffic Accidents unlike the Homicidal Dominance in the Present Study. Hence the study impresses upon the fact that All Complete Decapitations are not necessarily the actual Cause of Death, may be Postmortem in Nature and they are always associated with other injuries on the body.

\section{Conclusion}

Complete Decapitations are not always Ante mortem they can be Postmortem in Nature. Ante mortem Decapitations are carried out before Death or during the process of Death. Presence of Vital reactions of the Cut margins, Exangunations process, Subendocardial hemorrhages, and Respirations System Changes due to Aspiration of Blood are the indicators of Ante mortem Nature of the Complete Decapitations. In cases of Decomposed Decapitated Head, recovered lately DNA matching of the Head and Torso is important apart from the Sex, Age, Race etc Matching's. In all Homicidal Decapitations The body is always associated with Fatal or Near Fatal injuries of varied Nature. Complete Homicidal Decapitations are always an act to conceal the Identity, Invent Terror in Community, Reflects a Group, as a means of Punishment for interfering in their Functions or punishment for Betrayal or Disloyalty.

\section{References}

[1]. "Blows Head Off with Dynamite?". The Rhinelander Daily News. April 2, 1937. p. 7. Retrieved September 29, 2014 - via Newspapers.com.

[2]. (2003) "Guillotine death was suicide". BBC News. Retrieved 26 September 2008.

[3]. Weinberg, Jon (2008) "Sword of Justice? Be headings Rise in Saudi Arabia". Harvard International Review.

[4]. "Death Sentences and Executions 2013" Amnesty International. 2014. Retrieved 19 September 2014.

[5]. Francis Larson (2014) Severed: a history of heads lost and heads found Live right (1st Edtn) ISBN- 13: 978-0871404541.

[6]. Ann Fabian (2014)" Losing our Heads" review of Larson, s Severed Chronicle of Higher Education 1[1].

[7]. George W. Grayson (2009) "La Familia: Another Deadly Mexican Syndi- 
cate". Foreign Policy Research Institute. www.fpri.org

[8]. Türk EE, Püschel K, Tsokos M (2004) Features characteristic of homicide in cases of complete decapitation. The Am J For Med Pathol 25(1): 83-86.

[9]. Rothschild M, Schneider V (1999) Decapitation as a result of suicidal hanging. Forensic Sci Int 106(1): 55-62.

[10]. Shorrock K (2002) Suicidal decapitation by guillotine. The Am J Forensic Med and Pathol 23(1): 54-56.

[11]. Bahadır Kumral, Yalçın Büyük, Ümit N.Gündoğmuş (2012) Medico-legal evaluation of deaths due to decapitation. Rom J Leg Med 251-254.

[12]. Tsokos M, Türk EE, Uchigasaki S (2004) Pathologic features of suicidal complete decapitations. Forensic Sci Int. 139: 95-102.

[13]. Milovanovic' M (1929) Adipozna embolija kao uzrok oboljenja odnosno smrti. Srp Arh Celok Lek 12: 1051-61.

[14]. Milovanovic' M (1932) Kadaverozna adipozna embolija. Srp Arh Celok Lek 2: 81-90.
[15]. Brunel C, Fermanian C, Durigon M, Grandmaison GL (2010) Homicidal and suicidal sharp force fatalities: Autopsy parameters in relation to the manner of death. Forensic Sci Int 198: 150-154.

[16]. Mazzolo GM, Desinan L (2005) Sharp force fatalities: suicide, homicide or accident? A series of 21 cases. Forensic Sci Int 147S: S33-S35.

[17]. Uzün I1, Daregenli O, Sirin G, Müslümanoğlu O (2012) Identification procedures as a part of death investigation in Turkey. Am J Forensic Med Pathol 33(1): 1-3.

[18]. Byard RW, Gilbert JD (2004) Characteristic features of deaths due to decapitation. Am J Forensic Med Pathol 25: 129 -130.

[19]. Püschel K, Koops E (1987) Dismemberment and mutilation. Arch Kriminol 180: 28-40, 88-100.

[20]. Rajs J, Lundström M, Broberg M (1998) Criminal mutilation of the human body in Sweden: a thirty-year medico-legal and forensic psychiatric study. J Forensic Sci 43: 563-580. 